\title{
Contribution of Food Quality Management on the Growth of Food Service Industry in Rwanda: A Case of Lemigo Hotel
}

\author{
Sylvestre Mbanza*, Reginal Octove Muhoza and Jean Paul Mbabazi \\ Department of Hotel and Restaurant Management, \\ University of Tourism, Technology and Business studies, Rwanda \\ *Corresponding author: smbanza@gmail.com
}

\begin{abstract}
The study sought to assess the contribution of food quality management on the growth of food service industry in Rwanda, a case of Lemigo hotel. The study focused on identifying the procedures of food quality management, assessing the contribution of food quality management on the growth of the hotel and finding out the challenges of food quality management and the measures to be taken. By descriptive research design, questionnaires were distributed to 62 participants. The analysis of the data was done through descriptive statistics. The study concluded that the hotel provides some appropriate procedures which are used to maintain the food quality like purchasing the quality of raw food, receiving, storing and issuing the raw food items appropriately and using the right way of cooking method. Further the food quality management contributes to the growth of Lemigo Hotel since providing quality food increases the overall quality, the sales and the competition edge of the hotel. However, there are some challenges in food quality management like skills gap among employees. The study recommends setting up of appropriate standards that reduce risks and maintaining effective quality control on a regular basis among food production staff. Also, there is a need of employees' periodic training on food handling practices to improve their own knowledge and skills for improving their efficiency and quality products to the customers.
\end{abstract}

Keywords: Food quality management, growth, food service industry, hotel, restaurant

\section{Introduction}

Food quality issues have been a worldwide concern for a long time. Large number of populations are affected by food borne and health related complications annually emanating from bad food safety system management (Bintsis, 2017. Hence, attention has been given to the implementation of food quality management in most nations across the globe especially in the hotel industry (Klimpel, et.al, 2019).

According to Jones and Dent (2000), the United Kingdom (UK) hospitality industry is one of the fastest growing industries within the UK tourism industry and due to increased competition amongst hotels, hotel managers recognized the significance of the quality of their hotels' products and services. However, delivering a consistent level of quality products and services within hotel operations still face challenges and represent a major ongoing dilemma for the hotel sector (Tapiki, 2012).
According to a study conducted in Nepalese restaurant in Finland, customers have revealed that food quality is about the good smell, fresh and hygiene. In addition, the food quality relates to nutritious content as well as delicious quality (Karki \& Panthi, 2018). In Indonesia, many food businesses have increased such as restaurant, Food Street, café, food court, and so on. This research with a case study of Lemigo hotel has revealed that food and beverage quality play a significant role on customer satisfaction (Arlanda and Suroso, 2018)

In Africa, food borne diseases have been noticed and reported in the hospitality industry. For instance, the research conducted in Ghana in 2018 reported that 1 out of 40 people are affected by foodborne illnesses due to the poor quality of food in hospitality industry which costs a lot of millions of dollars every year (Lagerkvist et al., 2018). The foodborne diseases include diarrhea, cholera and typhoid and all of these diseases are caused by 
improper food handling that allows crosscontamination (Odonkor and Odonkor, 2020).

Quality of food has a positive influence on customer satisfaction; study findings suggested that food quality was the most influential predictor of customer loyalty in restaurant or hotel choice. The top three reasons for customers to patronize their target restaurants or hotels in the casual dining sector were food quality, service and atmospheric environment. Specifically, food quality was the most important attribute of overall restaurant service quality and is expected to have a positive relationship with customer satisfaction and loyalty (Mattila, 2001).

In Rwanda, food quality management has been incorporated within the strategic scope of food service industry and it is known as Strategic Management of Quality. It represented a vision of market-oriented management, i.e., with a view of opportunities before the competition and customer satisfaction, where market research has become more important for evaluating the market needs and how the competition stands (Republic of Rwanda, 2014).

Food quality management can be regarded as activities and procedures involved in ensuring that food that is consumed does not cause harm but accomplishes its desired purpose (FAO, 2011). Adoption of food quality management leads hotels to increase the success in the areas of profitability and market share. Today's hotel business performance and competitive advantages are based on production of good quality goods and provision of better services to the local and foreign customers and that are also used in organization marketing (Tsai et al, 2009).

This study was guided by the following research question:

1. What are the procedures of food quality management at Lemigo hotel?

2. What is the contribution of food quality management on the growth of Lemigo Hotel?

3. What are the challenges of food quality management and their measures at Lemigo hotel?

4. What are the measures to be taken to encounter the challenges in in food quality management?

\section{Related Literature and Studies}

This part illustrates the role of food quality management in backing the growth of food service industry. It shed light on food quality management procedures and the influence of food quality management on the growth of food service industry. In addition, this section shows the issues and measures to counteract the challenges found in the management of food quality particularly in the food service industry.

\section{Food quality management procedures in food service industry}

In food quality management, particularly within food production in a hotel, the first step to ensure the quality of food is maintained during purchasing and this is done based on the standard purchase specifications agreed between hotel and food supplier (Walker, 2008). Riegel and Reid (1988) conducted a study on food service purchasing and explained that one of the requirements of having foods of good quality at the hotel is to select the right food supplier who is able to provide the consistent food quality. However, the accuracy and time delivery are the most substantial concerns with suppliers. Accurate purchase of food item is very crucial not only in standard purchase specifications but also with the menus of the hotel (Chon and Sparrowe, 2000).

Receiving is a key step of food quality control in the catering operation (Walker, 2006). Henceforward, the supplier should provide the food items that match the order and if not, there is rejection of food items supplier to the hotel (Chon and Sparrowe, 2000). According to Dittmer and Griffin (1997), any procedures planned to purchase or receive food items have to incorporate two diverse categories that are perishable and non-perishable food stuffs. When these food stuffs comply the standards, then it is expected to have a good quality finished products.

Good quality management procedures in food service industry involves the elements of food production starting from food in the hotel, continuing in the food processing up to the food out which is food presentation. The input phase embraces purchasing procedures, receiving food items, staring and issuing food in the context of the hotel. On the other side, food processing embraces food preparation, cooking, holdings as well as regeneration. And then the output phase embodies food presentation (Huebbe and Rimbach, 2020). 
Both control and quality approaches support maintenance of food quality management in the food service industry and contribute to the satisfaction of customer. The control has to be done throughout the production food chain and it should be carried out every day with the purpose of achieving consistent food quality (Vrtiprah, 2001).

\section{The contribution of food quality management on the growth of food service industry}

The importance of offering quality food in the hotel or restaurant has been clarified by Lattin (2005) who pointed out that quality food in the hotels increases the overall quality of the hotel in different angles like the occupancy as well as average room rates. It also increases the competition edge of the hotel. Therefore, the main purpose of food service operators is to provide a profit and improve food sales by corresponding the customers' requirement.

Equally important, Kotas and Jayawardena (2004) emphasized that one of the importance of food quality in the hotel industry is a pleasant memory for hotel guests. That is why, food operations are among the critical component of the hotel industry in terms of satisfying the needs and expectations of guests. Furthermore, food operations improve the image of the hotel as well as hotel revenues (Riley, 2005). Additionally, Bosselman (2007) highlights that food operation in the hotel industry is used as a marketing tool which is used in providing competitive advantages.

Similarly, food quality in a hotel plays an imperative role in keeping customer satisfaction which is the source of hotel revenues and it is disclosed that that dissatisfaction of customer does not only stop customers of going to the hotel/restaurants but also customers tell their friends not to attend the hotel (Heung and Lam, 2003).

Again, provision of food quality is a crucial way to increase customer loyalty and retention and makes the most of hotel and restaurant business revenues since the repetition of customers employ more money on food (Ramdeen, 2007). Numerous studies have recognized food quality as a vital matter for economic performance. That is to say, maximizing price of product which upsurge the market share influences the return on investment (Kimes, 2001). Curry and Kadasah (2002) affirmed that having quality culture is influenced by the attitudes and perceptions of hotel employees towards the food quality. Therefore, food quality has to be interwoven with the customers and business culture to attain appropriate outcomes.

On the other side, food safety is the base of quality of food in the hotel and restaurant. The quality food is based on different safety processes starting from raw materials, methods of processing and people. Also, the safety of quality of food additives, packaging materials and methods, and production machines as well as many others have to be controlled based on Hazards Analysis and Critical Control Points (HACCP). In addition, Good Manufacturing Practices (GMP) are used for quality food in the hotel. The applicability of these food safety reduces food waste (Śmiechowska, and Kłobukowski, 2015)

\section{Challenges and measures for food quality management}

The management of food quality in food service industry suffers different challenges. Among them, storage process may harm the quality food. Therefore, food has to be stored in the appropriate place with safety environment standards with the purpose of improving the quality. Equally important, the kitchen personnel is widely characterized by employees with low skills based on lack of education, motivation or training, then it results in poor quality products.(Gomes, et.al, 2014).

Similarly, the hygienic quality of the foods is negatively influenced by purchasing low-quality of foods, storing food in the conditions that are not suitable and inappropriate cooking procedures. That is to say, lack of skilled employees is a big challenge in hotel and restaurant industry because cooking and storing foods through the use of incorrect techniques result in bad quality of food. So, once the food is mismanaged or contaminated at any level of food production from raw material up to the service level, the food potentially becomes harmful to human health and it is a challenge to the food quality (Wallace, 2014).

The use of standards guidelines during food production is considered as core value for risks reduction and maintenance of quality control. These standards have to be applied by staff throughout the production processes (Sandoff, 2005). Equally important, the employees' training is the ways of helping them to obtain the appropriate habits and use the correct operation procedures for improvement of food quality (East, 1993; Habiballah et al, 2017). This study therefore sought to establish 
the contribution of food quality management on the growth of food service industry in Rwanda, a case of Lemigo Hotel.

\section{Research Methodology}

This study employed qualitative and qualitative approaches. This section addresses various aspects of the research methodology used.

\section{Research Design}

According to Mugenda (2003) research design refers to a plan for collecting and utilizing data so that desired information can be obtained with a sufficient precision. The researchers used a descriptive research design to study the contribution of food quality management in the growth of food service industry in Rwanda.

\section{Population and sampling techniques}

The researchers selected the respondents from different departments to obtain the right respondents to give information about food quality management aspects. The population of this study was 62 persons from different departments; these persons were taken as sample from various sections as follows: 24 from restaurant, 18 from kitchen, 9 from accounting and finance, 5 from sales and marketing and 6 from storing and receiving department. Saunders et al., (2016) argue that when the population is small, the researcher can use the whole population as sample.

Therefore, the researcher used the whole populations (62) participants. The researchers formulated the items in the questionnaire according to the specific objectives of the study. The researchers set the questions that are clear and understandable in the line with the research questions. To ensure the collection of valid data, the researchers distributed the questionnaire to various groups of respondents.

\section{Statistical Treatment of Data}

In data analysis, the researcher used the frequency and percentage to analyze the responses and presentation was done using tables.

\section{Ethical Considerations}

The ethical rules that are likely to affect the quality of this study were given due consideration. These include: access and acceptance, informed consent, privacy and confidentiality. The respondents participated in the study willingly and were free to withdraw at any time.

\section{Findings and Discussion}

This section shows how the data was analyzed and presented the findings of the study.

\section{Demographic Characteristics}

Table 1 indicates the demographic characteristics of respondents whereby the majority of respondents in this study were in the age range of 18-30 with $41.9 \%$. On the other side female respondents were more than male respondents $51.6 \%$ and $48.4 \%$, respectively. This illustrates that female are mostly employed in hospitality industry particularly in hotels and restaurants. Educationally, the majority of respondents had completed secondary education (41.9\%). On the other side, respondents who completed bachelor's degree were $37.1 \%$ and $17.7 \%$ showed that they were vocational certificate holders. A big part of employees' experience ranging between 5-10 years who represented a percentage of $53.3 \%$ while $25.8 \%$ indicated their working experience as below 5 years. Some employees 20.9\% stayed there for more than 10 .

Table 1: Demographics of Respondents

\begin{tabular}{llcc}
\hline \multicolumn{1}{c}{ Variables } & \multicolumn{1}{c}{ Categories (Population: 62) } & Frequency & Percent (\%) \\
\hline \multirow{3}{*}{ Age } & $18-30$ & 26 & 41.9 \\
& $31-40$ & 22 & 35.5 \\
\multirow{4}{*}{ Gender } & $41-50$ & 10 & 16.1 \\
& Above 51 & 4 & 6.5 \\
\multirow{3}{*}{ Education } & Male & 30 & 48.4 \\
& Female & 32 & 51.6 \\
& Vocational certificate & 11 & 17.7 \\
& Secondary School complete & 26 & 41.9 \\
Working experience & Bachelor's degree & 23 & 37.1 \\
& Master's degree and above & 2 & 3.3 \\
& Below 5 years & 16 & 25.8 \\
& 5-10 years & 33 & 53.3 \\
& Above 10 years & 13 & 20.9 \\
\hline
\end{tabular}


Research Question One: What are the procedures of food quality management at Lemigo hotel?

Table 2 showed that $32.8 \%$ strongly agreed and $46.1 \%$ agreed that purchasing food items according to specifications standard improves food quality at Lemigo hotel. This was also affirmed by Walker (2008) who explained that the first step to ensure the food quality is to control it during purchasing. However, $13.7 \%$ were not sure. Oppositely $5.1 \%$ disagreed and $2.3 \%$ strongly disagreed with the statement. Also, respondents revealed that cooking food in appropriate methods improves the quality as $40.3 \%$ agreed and $32.2 \%$ strongly agreed while only $9.4 \%$ disagreed, $5.8 \%$ strongly disagreed and $12.3 \%$ were not sure. The researchers were also interested in whether applying hazard analysis and critical points raises the food quality. Majority of respondents agreed at $30.6 \%$ and $24.7 \%$ strongly agreed with the statement. This coincides with the findings by Śmiechowska and Kłobukowski (2015) who affirmed that the application of food safety procedures improves the quality food and reduces the wastage in the hotel. On the contrary, $15.9 \%$ of respondents disagreed and $10.5 \%$ strongly disagreed while only $18.3 \%$ were not sure.

Table 2: The procedures maintaining food quality management at Lemigo hotel in Rwanda

\begin{tabular}{|c|c|c|c|c|c|}
\hline Responses & SD & $\mathrm{D}$ & $\mathrm{N}$ & A & SA \\
\hline $\begin{array}{l}\text { Purchasing food items according to specifications standard } \\
\text { improve food quality at Lemigo hotel }\end{array}$ & $2.3 \%$ & $5.1 \%$ & $13.7 \%$ & $46.1 \%$ & $32.8 \%$ \\
\hline $\begin{array}{l}\text { Receiving food items matching to quality specified written on } \\
\text { purchasing order improve food quality }\end{array}$ & $6.7 \%$ & $8.4 \%$ & $15.3 \%$ & $41.4 \%$ & $28.2 \%$ \\
\hline $\begin{array}{l}\text { Storing and issuing food items in appropriate conditions } \\
\text { optimize food quality at Lemigo hotel }\end{array}$ & $6.9 \%$ & $12.5 \%$ & $14.7 \%$ & $36.3 \%$ & $29.6 \%$ \\
\hline $\begin{array}{l}\text { Preparation food items according to the standardized recipe } \\
\text { improve food quality at Lemigo hotel }\end{array}$ & $9.2 \%$ & $13.5 \%$ & $17.1 \%$ & $33.5 \%$ & $26.7 \%$ \\
\hline Generation and presentation food raise the quality of food & $11.4 \%$ & $14.2 \%$ & $16.8 \%$ & $28.7 \%$ & $28.9 \%$ \\
\hline $\begin{array}{l}\text { Cooking food in appropriate methods improve quality of food at } \\
\text { Lemigo hotel }\end{array}$ & $5.8 \%$ & $9.4 \%$ & $12.3 \%$ & $40.3 \%$ & $32.2 \%$ \\
\hline $\begin{array}{l}\text { Applying hazard analysis and critical points (HACCP) raise the } \\
\text { food quality }\end{array}$ & $10.5 \%$ & $15.9 \%$ & $18.3 \%$ & $30.6 \%$ & $24.7 \%$ \\
\hline $\begin{array}{l}\text { Making quality inspection improve the food quality served to } \\
\text { the customer at Lemigo hotel }\end{array}$ & $8.6 \%$ & $14.9 \%$ & $17.2 \%$ & $32 \%$ & $27.3 \%$ \\
\hline
\end{tabular}

Table 3: The contribution of food quality management on the growth of Lemigo hotel in Rwanda

\begin{tabular}{|c|c|c|c|c|c|}
\hline Responses & SD & $\mathrm{D}$ & $\mathrm{N}$ & $A$ & SA \\
\hline $\begin{array}{l}\text { Food quality management increase customer satisfaction } \\
\text { at Lemigo hotel }\end{array}$ & $2.6 \%$ & $4.5 \%$ & $13.7 \%$ & $44.4 \%$ & $34.8 \%$ \\
\hline $\begin{array}{l}\text { Food quality management improve image of hotel and } \\
\text { revenues at Lemigo hotel }\end{array}$ & $5.1 \%$ & $7.5 \%$ & $14.8 \%$ & $41.4 \%$ & $31.2 \%$ \\
\hline $\begin{array}{l}\text { Food quality management influence customer retention } \\
\text { and loyalty }\end{array}$ & $8.4 \%$ & $12.7 \%$ & $16.3 \%$ & $34.7 \%$ & $27.9 \%$ \\
\hline $\begin{array}{l}\text { Food quality management increase sales volume at } \\
\text { Lemigo hotel }\end{array}$ & $5.9 \%$ & $9.1 \%$ & $15.6 \%$ & 35.7 & $33.7 \%$ \\
\hline $\begin{array}{l}\text { Food quality management reduce costs of food } \\
\text { production and waste }\end{array}$ & $3.4 \%$ & $10.2 \%$ & $13.7 \%$ & $40.8 \%$ & $31.9 \%$ \\
\hline $\begin{array}{l}\text { Food quality management increase productivity and } \\
\text { market share for Lemigo hotel }\end{array}$ & $8.4 \%$ & $9.3 \%$ & $14.9 \%$ & $38.9 \%$ & $28.5 \%$ \\
\hline
\end{tabular}

Research Question 2: What is the contribution of food quality management on the growth of Lemigo Hotel?

Table 3 illustrates the contribution of food quality management on the growth of Lemigo hotel. The findings indicated that food quality management increases customer satisfaction at the hotel as $44.4 \%$ agreed and $34.8 \%$ strongly agreed with the statement while $13.7 \%$ were not sure, $4.5 \%$ disagreed and $2.6 \%$ strongly disagreed. On other hand, food quality management improves image of the hotel as $41.4 \%$ agreed and $31.2 \%$ strongly agreed with the statement while $14.8 \%$ were not sure, $7.5 \%$ disagreed and $5.1 \%$ strongly disagreed. Further, results reveal that food quality management influences customer retention and 
loyalty as $27.9 \%$ strongly agreed, $34.7 \%$ agreed while $16.3 \%$ were not sure, $12.7 \%$ disagreed and $8.4 \%$ strongly disagreed.

The findings show that food quality management increases sales volume as $33.7 \%$ strongly agreed and $35.7 \%$ agreed. This is also supported by Lattin (2005) who argued that good food quality management is the sources of hotel profit. On the other hand, respondents asserted that food quality management reduce costs of food production and waste as $31.9 \%$ strongly agreed and $40.8 \%$ agreed while $13.7 \%$ were not sure, $10.2 \%$ and $3.4 \%$ disagreed and strongly disagreed respectively.

Last but not least, respondents making up 38.9\% and $28.5 \%$ agreed and strongly agreed that food quality management increase productivity and market share but $9.3 \%$ and $8.4 \%$ disagreed and strongly disagreed with the statement while $14.9 \%$ were not sure. Therefore, food quality management plays as great deal toward the performance of the hotel.

Research Question 3: What are the challenges of food quality management and their measures at Lemigo hotel?

The table 4 indicates the challenges faced by food quality management at Lemigo hotel. The findings revealed that $15.1 \%$ strongly agreed and $26.4 \%$ agreed that there is a skills gap among the employees in maintaining food quality management. Wallace (2014) point out those low skills of employees based on uneducated or untrained workers results in poor food quality management. On other hand researchers asked whether inadequate equipment is the challenges facing the food quality management at Lemigo hotel where by $12.9 \%$ strongly agreed and $20.8 \%$ agreed while $23.6 \%$ were not sure. Those who disagreed were $28.1 \%$ and $14.6 \%$ strongly disagreed.

The researchers further sought to establish whether insufficient and poor purchasing of raw food materials needed to produce food such poor quality of fruits, flours and other food items is the challenge for food quality management at the hotel. Table 4: The challenges facing the food quality management at Lemigo hotel in Rwanda

\begin{tabular}{|c|c|c|c|c|c|}
\hline Challenges & SD & D & $\mathbf{N}$ & A & SA \\
\hline $\begin{array}{l}\text { Skills gap among employees in maintaining food quality } \\
\text { management }\end{array}$ & $13.5 \%$ & $27.2 \%$ & $17.8 \%$ & $26.4 \%$ & $15.1 \%$ \\
\hline Inadequate equipment & $14.6 \%$ & $28.1 \%$ & $23.6 \%$ & $20.8 \%$ & $12.9 \%$ \\
\hline $\begin{array}{l}\text { Poor purchasing raw food materials to produce food such } \\
\text { poor quality of fruits, flours and other items }\end{array}$ & $15.8 \%$ & $24.9 \%$ & $25 \%$ & $21.7 \%$ & $12.6 \%$ \\
\hline $\begin{array}{l}\text { Not enough skills of doing inventory and controlling cold } \\
\text { room temperature }\end{array}$ & $14.3 \%$ & $16.6 \%$ & $26.7 \%$ & $27.5 \%$ & $14.9 \%$ \\
\hline Insufficient hygiene of kitchen equipment and employees & $15.9 \%$ & $25.5 \%$ & $24.8 \%$ & $17.3 \%$ & $16.5 \%$ \\
\hline
\end{tabular}

Table 5: Measures encountering the challenges facing the food quality management at Lemigo hotel in Rwanda

\begin{tabular}{lccccc}
\multicolumn{1}{c}{ Measures } & SD & D & N & A & SA \\
\hline Providing employees training & $2.5 \%$ & $8.3 \%$ & $5.4 \%$ & $42.2 \%$ & $39.6 \%$ \\
Setting up appropriate standards and procedures for kitchen & $4.6 \%$ & $15.9 \%$ & $10.9 \%$ & $35.9 \%$ & $32.7 \%$ \\
employees to produce food quality & & & & & \\
Follows the HACCP procedures in handling food & $4.6 \%$ & $9.9 \%$ & $4.9 \%$ & $41.9 \%$ & $38.7 \%$ \\
Applying recoding and reporting system & $8.7 \%$ & $7.9 \%$ & $18.2 \%$ & $37.6 \%$ & $27.6 \%$ \\
\hline
\end{tabular}

The results indicate that $21.7 \%$ agreed and $12.6 \%$ strongly agreed while $24.9 \%$ disagreed and $15.8 \%$ strongly disagreed, $25 \%$ were not sure. In addition, the researchers asked whether not enough skills of doing inventory and controlling cold room temperature is the challenges facing food quality management at the hotel. The result show that $27.5 \%$ agreed and $14.9 \%$ strongly agreed while $26.7 \%$ were not sure. On the other hand, $16.6 \%$ disagreed and $14.3 \%$ strongly disagreed. Finally, respondents indicated that insufficient hygiene of kitchen equipment and employees is the challenge facing food quality management as $16.5 \%$ strongly agreed and $17.3 \%$ agreed, while $24.8 \%$ were not sure; and $25.5 \%$ and $15.9 \%$ disagreed and strongly agreed respectively.

Research Question 4: What are the measures to be taken to encounter the challenges in in food quality management?

Table 5 describes the measures against the challenges faced by the food quality management. The result indicates that $39.6 \%$ strongly agreed and $42.2 \%$ agreed that providing employees training is a 
good measure in improving the employees' skills. According to East (1993), the employees training is the good way of helping workers to receive the appropriate habits provide the correct operation procedures which improve food quality in the hotel. However, some respondents $5.4 \%$ were not sure and only $8.3 \%$ disagreed and $2.5 \%$ strongly disagreed. The respondents further accepted the fact that setting up appropriate standards and procedures for kitchen employees to produce food quality at agreement is an ideal measure as $32.7 \%$ strongly agreed and $35.9 \%$ agreed while only $10.9 \%$ were not sure.

By the same token, respondents revealed that following the HACCP procedures in handling food improves the quality food as $38.7 \%$ strongly agreed and $41.9 \%$ agreed while only $4.9 \%$ were not sure, 9.9\% disagreed and $4.6 \%$ strongly disagreed. In addition, respondents asserted that applying recoding and reporting system optimizes food quality at Lemigo hotel as $37.6 \%$ agreed and $27.6 \%$ strongly agreed. Therefore, the list of measures in the questionnaire were all considered appropriate.

\section{Conclusion and Recommendations}

The study concludes that the hotel provides some appropriate procedures used to maintain the food quality such as purchasing the quality of raw food, appropriate manner of receiving, storing and issuing the raw food items and using the right way of cooking method. Further the food quality management contributes to the growth of Lemigo hotel since providing quality food increase the overall quality of the hotel, the sales and the competition edge of the hotel. Also, the study concludes that there are some challenges in food quality management at Lemigo hotel like skills gap among employees.

The study recommends that Lemigo hotel management should set up appropriate standards system that reduce risks and maintain effective quality control on a regular basis among food production staff through hotel food production processes and leads to consistent product quality. Due to the skills gap among employees, the study recommends the hotel management to provide the employees periodic training program on food handling practices to improve their own knowledge and skills for improving own efficiency and quality products to the customers.

\section{Reference}

Arlanda, R., \& Suroso, A. (2018). The Influence of Food \& Beverage Quality, Service Quality, Place, and Perceived Price to Customer Satisfaction and Repurchase Intention. Journal of Research in Management, 1 (1), 28-37.

Bintsis, T. (2017). Foodborne pathogens. AIMS microbiology, 3(3), 529-563. https://doi.org/10.3934/microbiol.2017.3.5 29.

Bosselman, R. H. (2007). Managing food and beverage operations in lodging organizations. In D.G. Rutherford, and M.J. O'Fallon (eds.) Hotel management and operations, $4^{\text {th }}$ ed. New Jersy: John Wiley \& Sons, Inc.

Chon, K., \& Sparrowe, R.T. (2000), Welcome to Hospitality: An Introduction, 2nd ed., Cengage Delmar Learning, New York, NY.

Curry, A., \& Kadasah, N. (2002) Focusing on key elements of TQM - evaluation for sustainability. The TQM Magazine, 14(4), 207-216.

Dittmer, P.R., \& Griffin, G.G. (1997). Dimensions of the Hospitality Industry: An Introduction. 2nd ed. New York: John Wiley \& Sons, INC.

East, J. (1993). Managing Quality in the Catering Industry. Kingston upon Surrey: Croner Publications Ltd.

Food and Agriculture Organization, FAO. (2011). Cost-effective management tools for ensuring food quality and safety for small and medium agro-industrial enterprises: Module 2: Systems and tools for improving quality and safety management in agroindustries. Geneva: FAO.

Gomes, C.C.B., Lemos, G.F.C., Silva, M.C., Hora, I.M.C.., \& Cruz, A.G. (2014). Training of Food Handlers in a Hotel: Tool for Promotion of the Food Safety. Journal of Food Safety, 34(3),218-223.

Habiballah, M.A., Al-Shakhsheer, F., \& Al-Ababneh, M.M. (2017). Restaurant Employees' Food Handling Practices in Irbid City, Jordan. Journal of Tourism and Hospitality Management 5(1) 81-89.

Heung, V.C.S. and Lam, T. (2003) Customer complaint behaviour towards hotel restaurant services. International Journal of Contemporary Hospitality Management, 15(5), 283-289. 
Huebbe, P., \& Rimbach, G. (2020). Historical Reflection of Food Processing and the Role of Legumes as Part of a Healthy Balanced Diet. Foods, 9, 1056; doi:10.3390/foods9081056

Jones, P. and Dent M. (2000) Lessons in consistency: statistical process control in Forte plc. The TQM Magazine, 6 (1), 18-23.

Karki, D., \& Panthi, A. (2018). How Food Quality, Price, Ambiance and Service Quality Effects Customer Satisfaction: A study on Nepalese Restaurants in Finland. A thesis submitted in partial fulfilment of the degree of bachelor in tourism and hospitality management at the Haaga-Helia, University of Applied Sciences.

Kimes, S.E. (2001) How Product Quality Drives Profitability: The Experience at Holiday Inn. The Cornell Hotel and Restaurant Administration Quarterly, 42(3), 25-28.

Klimpel, T. Kuhn, J. M“unster, D. D. D“orge, R. Klapper, J. andKochmann,UFood Safety Considerations. InParasitesofMarine Fish and Cephalopods, pp. 149-155, Springer, Berlin, Germany, 2019.

Kotas, R., and Jayawardena, C. (2004) Profitable food \& beverage management. London: Hodder \& Stoughton Educational.

Lagerkvist, C. J., Amuakwa-Mensah, F., \& TeiMensah, J. (2018). How consumer confidence in food safety practices along the food supply chain determines food handling practices: Evidence from Ghana. Food Control, 93, 265-273. doi:10.1016/j.foodcont.2018.06.019

Lattin, G.W. (2005). The lodging and food service industry. Michigan: The Educational Institute of the American Hotel \& Motel Association.

Mattila, A.S. (2001) Emotional Bonding and Restaurant Loyalty. Cornell Hotel and Restaurant Administration Quarterly, 42, 73-79.http://dx.doi.org/10. 1016/S00108804(01)81012-0

Mugenda, O.M., \& Mugenda, A.G. (2003) Research Methods, Quantitative and Qualitative Approaches. Nairobi: Acts Press.

Odonkor, S. T., \& Odonkor, C, J, A. (2020). An Assessment of Food Safety Knowledge and Practices in the Ghanaian Hospitality
Industry. Journal of food safety. Volume 2020, Article ID 5618492, 9 pages https://doi.org/10.1155/2020/5618492

Ramdeen, C., Santos, J., and Chatfield, H.K. (2007) Measuring the cost of quality in a hotel restaurant operation. International Journal of Contemporary Hospitality Management, 19(4), 286-295.

Riegel, C.D \& Reid, R.D. (1988). Food-Service Purchasing: Corporate Practices. Cornell Hotel and Restaurant Administration Quarterly. 29(1):24-29. Doi:10.1177/0010 88048802900112

Riley, M. (2005) Food and beverage management a review of change. International Journal of Contemporary Hospitality Management, 17(1), 88-93.

Republic of Rwanda, RoR. (2014). National food and nutrition policy 2013 - 2018. Kigali: Republic of Rwanda.

Sandoff, M. (2005). Customization and standardization in hotels - a paradox or not? International Journal of Contemporary Hospitality Management, 17(6), 529-535

Śmiechowska, M., \& Kłobukowski, F. (2015). Quality Assurance of Food versus Limiting Food Loss and Waste. Zarzqdzanie i Finanse Journal of Management and Finance, 13(2), 93-103.

Saunders M., Lewis P., Thornhill A. (2016). Research methods for business students. Munich: Pearson.

Tapiki, S. (2012). Quality Management in Tourism and Hospitality: An Exploratory Study among Tourism Stakeholders. International Journal of Economic Practices and Theories 2(2), 53-61.

Tsai, H., Song, H., \& Wong, K. K. F. (2009). Tourism and hotel competitiveness research. Journal of Travel \& Tourism Marketing. 26:5-6, 522546, DOI: 10.1080/10548400903163079

Vrtiprah, V. (2001) Managing quality in hotel excelsior. Journal of Quality Assurance in Hospitality \& Tourism, 2(3/4), 111-126.

Wallace C A. (2014). Food Safety Assurance Systems: Hazard Analysis and Critical Control

Walker, J.R. (2006) Introduction to Hospitality. New Jersey: Prentice Hall, Pearson Education, Inc.

Walker, J.R. (2008) Exploring the hospitality industry. Upper Saddle River: Pearson Prentice Hall. 